\title{
PERANCANGAN APLIKASI KINERJA PESERTA DIDIK DI SEKOLAH MADRASAH ALIYAH NEGERI 14 JAKARTA
}

\author{
Zaky Ramdhani ${ }^{1}$, Dwi Yulistyanti ${ }^{2}$, Dwi Marlina ${ }^{3}$ \\ ${ }^{1,2,3}$ Teknik Informatika, Fakultas Teknik dan Ilmu Komputer, Universitas Indraprasta PGRI 1,2,3 \\ Jalan Raya Tengah No.80, Kelurahan Gedong, Pasar Rebo, Jakarta Timur \\ 1.
}

\begin{abstract}
ABSTRAK
Instansi pendidikan membutuhkan sistem untuk mengumpulkan, mengolah, menyimpan, serta memberikan informasi. Media komputer dan aplikasi membantu menghasilkan informasi yang cepat, akurat. Pengolahan data kinerja peserta didik disekolah MAN 14 Jakarta dilakukan secara manual. Rumusan masalah penelitian adalah merancang sistem kinerja peserta didik disekolah MAN 14 Jakarta. Tujuan penelitian adalah membuat sistem aplikasi kinerja peserta didik terkait pegolahan data kinerja siswa MAN 14 Jakarta menjadi efektif dan efisien. Metode perancangan menggunakan Diagram Alir Data (DAD). Metode penelitian dengan metode grounded theory dan kualitatif deskriptif. Pengembangan sistem menggunakan metode terstrukur dengan paradigma siklus hidup klasik, memiliki kelebihan setiap tahap didefinisikan jelas, berkelanjutan dan saling mengkoreksi kesalahan. Penelitian ini membuat rancangan sistem informasi kinerja peserta didik berbasis Java Netbeans. Aplikasi ini dikemudian hari dapat berkembang untuk pencatatan proses administrasi keuangan, pendaftaran peserta didik baru dan penambahan beberapa prosedur enkripsi data untuk meningkatkan sistem keamanan aplikasi. Simpulan dibuatnya aplikasi dapat memberikan fasilitas kecepatan dan ketepatan proses pendataan kinerja sehingga memudahkan pekerjaan guru dan staff.
\end{abstract}

Kata Kunci: Rancangan Aplikasi, Kinerja Peserta Didik, MAN 14 Jakarta

\begin{abstract}
Educational institutions need a system to collect, process, store, and provide information. Computer media and applications help produce fast, accurate information. Processing of student performance data in MAN 14 Jakarta is done manually. The formulation of the research problem is to design a student performance system at MAN 14 Jakarta. This research aims to make a student performance application system related to processing student performance data at MAN 14 Jakarta to be effective and efficient. The design method uses a Data Flow Diagram (DAD). The research method is grounded theory and descriptive qualitative practice. System development using a structured approach with the classical life cycle paradigm has the advantages of each stage is clearly defined, continuous, and correcting each other for errors. This study designed a student performance information system based on Java Netbeans. This application can develop this application in the future for recording financial administration processes, registration of new students, and the addition of several data encryption procedures to improve the application security system. The conclusion is that the application can provide facilities for the speed and accuracy of the performance data collection process to facilitate the work of teachers and staff.
\end{abstract}

Key Word: Application Design, Student Performance, MAN 14 Jakarta.

\section{PENDAHULUAN}

Sebuah instansi pendidikan selalu membutuhkan sistem untuk mengumpulkan, mengolah, menyimpan, serta memberikan informasi. Informasi yang baik adalah informasi yang disajikan tepat pada saat dibutuhkan. Informasi yang terlambat menjadi tidak ada nilainya karena berkaitan erat dalam pemngambilan keputusan (Hartono, 2013). Salah satu pengelolaan data yang dilakukan sekolah adalah pengelolaan data siswa, data nilai siswa, data mata pelajaran, dan data absensi.
Sekolah membutuhkan sistem yang mendukung kegiatan di sekolah salah satunya adalah sistem informasi kinerja peserta didik. Sistem ini berfungsi sebagai sarana yang digunakan untuk menyampaikan data informasi kinerja peserta didik kepada orang tua siswa. Penilaian kinerja (Performance Apprasial) adalah suatu proses yang memungkinkan organisasi mengetahui, mengevaluasi, mengukur dan menilai kinerja anggota - anggotanya secara tepat dan akurat (Sihombing, 2015). Sistem informasi kinerja peserta didik yang baik dan 
sistematik sangat berpengaruh besar dalam menunjang kelancaran kegiatan belajar dan mengajar yang nantinya diharapkan dapat meningkatkan kualitas pendidikan siswa. Kebutuhan tentang informasi kinerja peserta didik sangat penting untuk orang tua siswa, mengingat orang tua yang ingin mengontrol kinerja anaknya di sekolah sebagai kepuasan orang tua terhadap sekolah untuk mengetahui perkembangan anaknya.

Menurut Djahir dan Pratita, (2015) mengemukakan bahwa sistem adalah kumpulan / grup dari subsistem / bagian / komponen apapun, baik fisik ataupun nonfisik yang saling berhubungan satu sama lain dan bekerja sama secara harmonis untuk mencapai satu tujuan tertentu.

Menurut Tata Sutabri, (2012) menjelaskan bahwa informasi adalah data yang telah diproses ke dalam suatu bentuk yang mempunyai arti bagi si penerima dan mempunyai nilai nyata dan terasa bagi keputusan saat itu atau keputusan mendatang.

Menurut (Rizky, 2019) Perancangan adalah sebuah proses untuk mendefinisikan sesuatu yang akan dikerjakan dengan menggunakan teknik yang bervariasi serta didalamnya melibatkan deskripsi mengenai arsitektur serta detail komponen dan juga keterbatasan yang akan dialami dalam proses pengerjaannya.

Menurut (Ramzi, 2013) Aplikasi merupakan penerapan, menyimpan sesuatu hal, data, permasalahan, pekerjaan dalam suatu sarana atau media yang dapat digunakan untuk menerapkan atau mengimplementasikan hal atau permasalahan yang ada sehingga berubah menjadi suatu bentuk yang baru tanpa menghilangkan nilai-nilai dasar dari hal data, permasalahan dan pekerjaan itu sendiri.

Menurut (Sihombing, 2015) Penilaian kinerja merupakan suatu fungsi dari motifasi dan kemampuan. Untuk menyelesaikan tugas atau pekerjaan seseorang sepatutnya memiliki derajat kesediaan dan tingkat kemampuan. Kesediaan dan keterampilan seseorang tidaklah cukup efektif untuk mengerjakan suatu tanpa pemahaman yang jelas tentang apa yang dikerjakan dan bagaimana mengerjakannya. Kinerja merupakan perilaku nyata yang ditampilkan setiap orang sebagai prestasi kerja yang dihasilkan oleh karyawan sesuai dengan perannya dalam perusahaan.

Hasil penelitian yang dijadikan acuan atau pembanding dalam kajian penelitian ini adalah penelitian yang dilakukan oleh Arizal dkk (2016) menunjukkan bahwa perancangan aplikasi penilaian kinerja guru di UPT SDN Kebonagung memberi dampak peningkatan prestasi pada peserta didik. Penelitian lain yang dilakukan oleh Saputro dkk (2020) menunjukkan bahwa rancangan aplikasi sistem informasi akademik sekolah pada SMP Muttaqien Jakarta berbasis Java memberi kemudahan pengelola pendidikan dalam memberikan laporan yang akurat kepada kepala sekolah maupun sebaliknya juga mempercepat kinerja pengelola sekolah dalam proses pembuatan laporan serta membuat data sekolah.

Sistem informasi kinerja peserta didik yang ada saat disekolah MAN 14 Jakarta menggunakan cara manual, yakni ketika guru ingin memberikan laporan kinerja peserta didik kepada orang tua harus menginformasikan terlebih dahulu kepada siswa menggunakan surat yang akan ditujukan kepada orang tua untuk hadir ke sekolah guna memberikan laporan kinerja anaknya selama berada di sekolah, sehingga memerlukan banyak waktu dan biaya untuk melakukan kegiatan tersebut.

Rumusan masalah pada penelitian ini adalah bagaimana merancang dan membangun sistem informasi hasil kinerja peserta didik pada MAN 14 Jakarta berbasis Java, dan merancang sistem pengarsipan data hasil kinerja siswa mulai dari data siswa, data guru, data nilai akhir dan data absensi siswa, serta mempermudah guru dalam pembuatan laporan nilai siswa.

Tujuan penelitian ini adalah membuat perancangan sistem pengolahan data peserta didik di sekolah MAN 14 Jakarta yang dapat digunakan untuk mengelola data-data siswa, guru, nilai dan absensi peserta didik yang dapat menangani pembuatan laporan, menghasilkan aplikasi kinerja peserta didik yang dapat digunakan oleh staff MAN 14 Jakarta untuk memasukan nilai siswa secara terstruktur, dan menghasilkan aplikasi kinerja 
peserta didik yang dapat memudahkan proses pengolahan informasi dan data agar tersimpan dengan baik sehingga tidak mudah hilang.

\section{METODE PENELITIAN}

Metode penelitian ini menggunakan metode penelitian grounded theory dan metode kualitatif deskriptif. Pendekatan grounded theory ialah pengembangan suatu teori yang berhubungan erat kepada konteks peristiwa yang dipelajari. Sedangkan penelitian kualitatif deskriptif bertujuan untuk menggambarkan, melukiskan, menerangkan, menjelaskan dan menjawab secara lebih rinci permasalahan yang akan diteliti dengan mempelajari semaksimal mungkin seorang individu, suatu kelompok atau suatu kejadian (Sugiyono, 2016).

Peneliti menggunakan metode deskriptif kualitatif untuk menggambarkan lebih jelas tentang pemanfaatan perancangan aplikasi kinerja peserta didik dengan cara mendapatkan informasi dari pihak terkait (staff TU dan guru) melalui pertanyaanpertanyaan terstruktur yang sudah disusun dalam format wawancara.

Tempat penelitian dilakukan di MAN 14 Jakarta, waktu penelitian dilaksanakan selama 5 bulan, mulai dari April sampai dengan Agustus 2021. Metode pengumpulan data yang digunakan adalah wawancara, observasi, dan studi pustaka. Wawancara dilakukan dalam bentuk tanya jawab kepada Staff pelayanan/ TU serta guru/ wali kelas terkait untuk memperoleh data atau informasi secara mendalam mengenai pengelolaan data informasi di MAN 14 Jakarta. Jenis pertanyaan yang digunakan adalah pertanyaan terbuka yang memungkinkan dapat menggali lebih dalam pernyataan yang disampaikan oleh narasumber. Tehnik observasi dalam penelitian ini dilakukan untuk mengumpulkan data secara langsung untuk mengetahui hal yang berkaitan dengan sistem yang sedang berjalan dan mengamati jalannya informasi yang dianggap penting pada MAN 14 Jakarta. Sedangkan untuk tehnik pengumpulan data secara dokumentasi yang dilakukan dalam penelitian ini adalah mencatat penilaian kinerja siswa di MAN 14 Jakarta yang saat ini digunakan. Studi pustaka yang dilakukan oleh peneliti adalah dengan merujuk sumber bacaan yaitu jurnal,artikel dan penelitian yang terdokumentasi di perpustakaan Universitas Indraprasta PGRI.

Langkah pengembangan sistem dilakukan dalam perancangan aplikasi kinerja peserta didik di Madrasah Aliyah Negeri 14 Jakarta Timur berbasis Java Netbeans. dalam membuat langkah-langkah pengembangan sistem, digunakan metode terstruktur dengan paradigma siklus hidup klasik model air terjun. Langkah-langkah pengembangan sistem aplikasi kinerja peserta didik yaitu analisis kebutuhan sistem, studi literatur, pengumpulan data dan perancangan sistem, pengkodean sistem, pengujian sistem.

\section{HASIL DAN PEMBAHASAN}

Hasil penelitian adalah merancang sistem informasi kinerja peserta didik dengan aplikasi berbasis java netbeans, Metode perancangan menggunakan Diagram Alir Data (DAD). Aturan sistem informasi kinerja peserta didik yang diusulkan pada MAN 14 Jakarta adalah sebagai berikut :

1. Staff TU sebagai admin akan login menggunakan nama pengguna dan kata sandi.

2. Admin masuk ke dalam menu dan memilih salah satu form data dan laporan.

3. Admin menginput data guru.

4. Admin menginput data murid.

5. Admin menginput data mata pelajaran.

6. Admin membuat laporan absensi.

7. Admin membuat laporan nilai.

Berikut ini merupakan gambaran tentang sistem yang diusulkan pada sistem informasi kinerja peserta didik pada MAN 14 Jakarta.

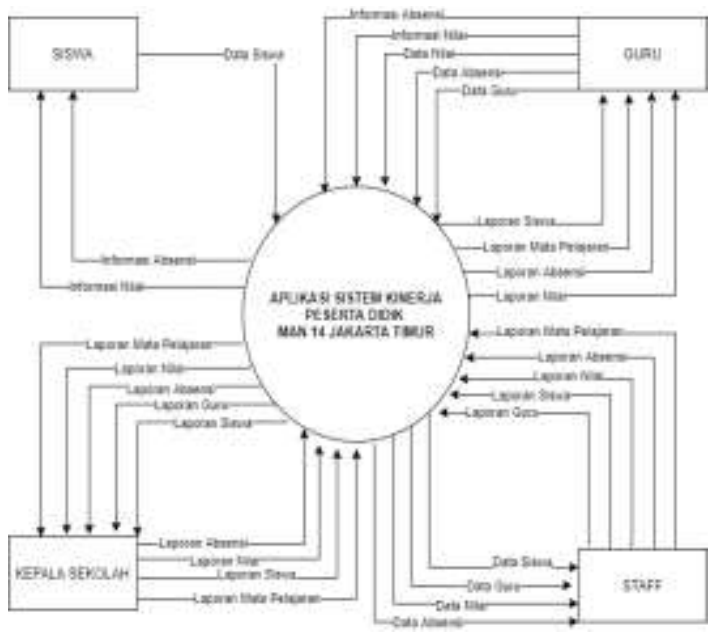

Gambar 1. Diagram Konteks 


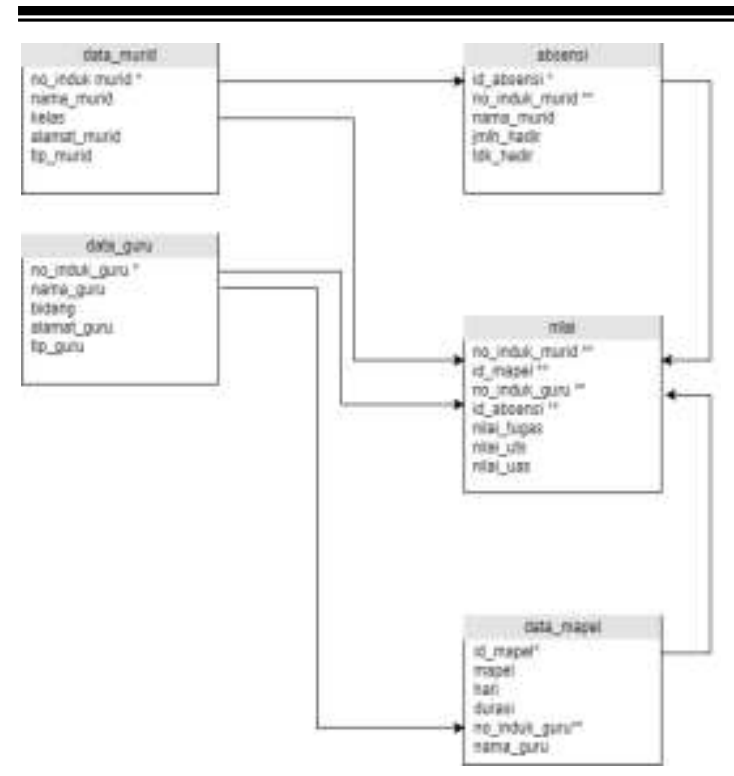

Gambar 2. Normalisasi

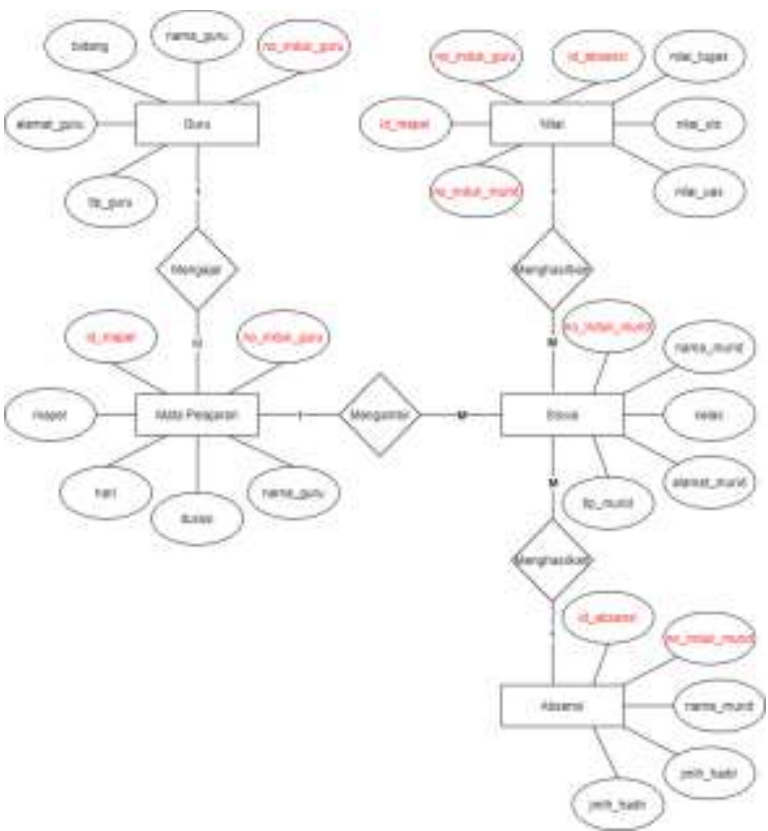

Gambar 3. ERD (Entity Relationship Diagram)

\section{Tampilan Layar dan Penjelasan}

1) Tampilan Masuk

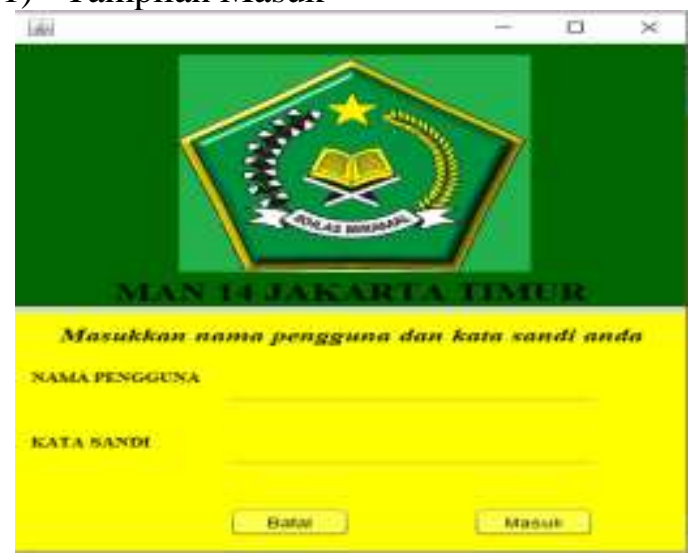

Gambar 4. Masuk (Login)
Pada Tampilan ini Staff harus melakukan masuk (Login) terlebih dahulu agar dapat membuka menu - menu

2) Tampilan Menu Utama

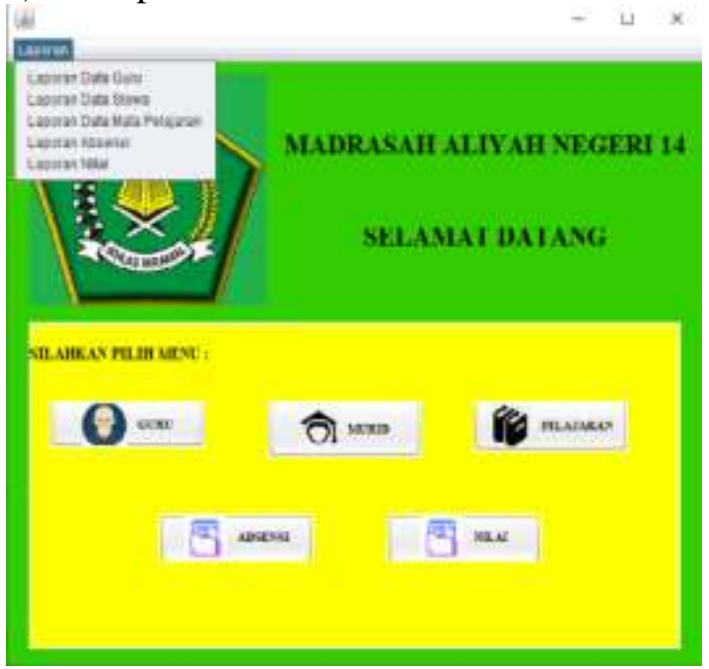

Gambar 5. Menu Utama

Ini adalah tampilan menu utama yang didalamnya terdapat menu-menu termasuk penginputan data.

\section{3) Tampilan Form Data Siswa}

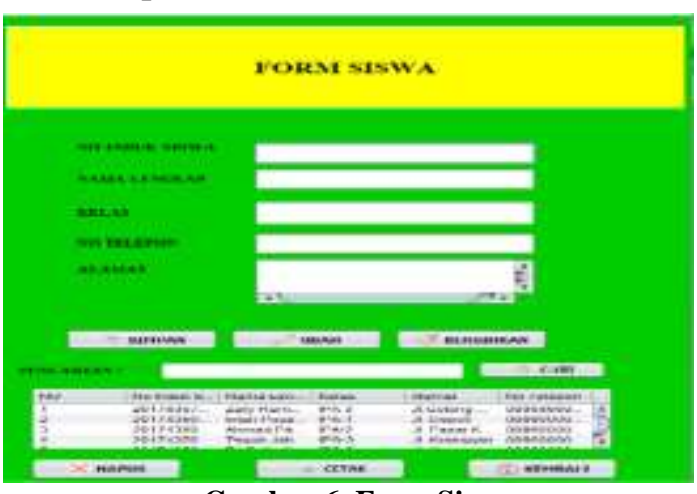

Gambar 6. Form Siswa

Pada form ini adalah untuk penginputan data siswa dimana terdapat no induk siswa, nama, kelas, alamat dan no telepon.

4) Tampilan Form Data Guru

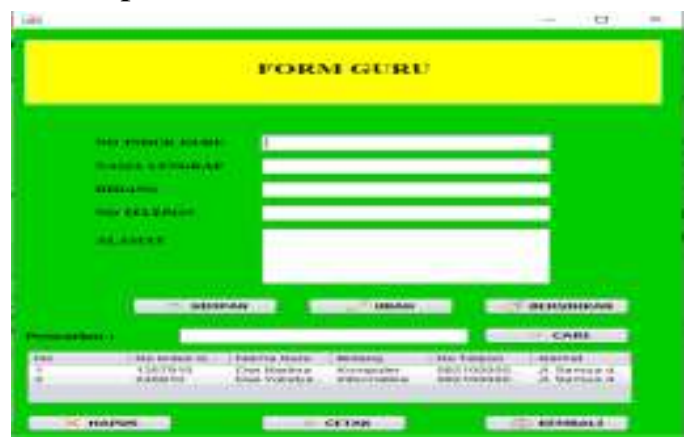

Gambar 7. Form Guru

999 | Perancangan Aplikasi Kinerja Peserta Didik di Sekolah Madrasah Aliyah Negeri 14 Jakarta 
Pada form ini adalah untuk penginputan data guru dimana terdapat no induk guru, nama, bidang, alamat dan no telepon.

\section{5) Tampilan Form Data Mata Pelajaran}

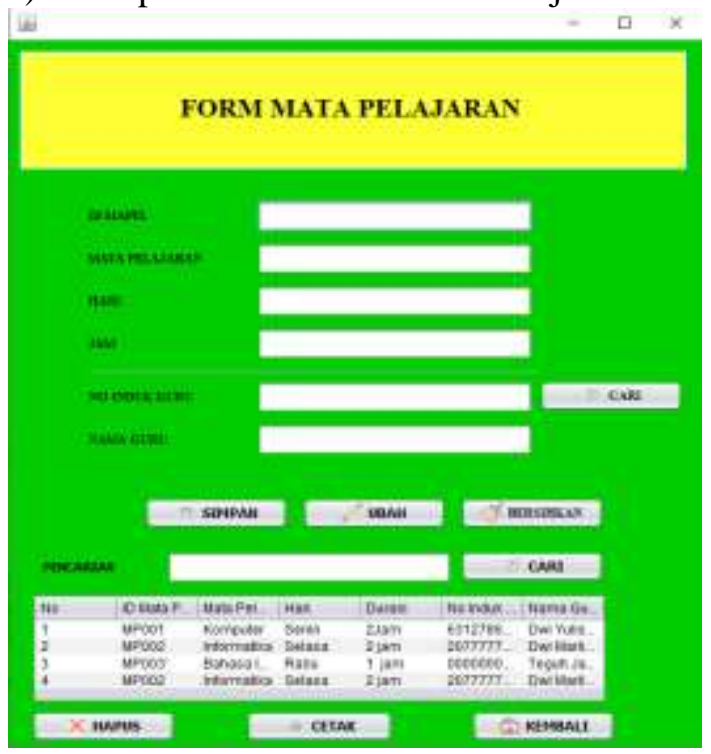

Gambar 8. Form Mata Pelajaran

Pada form ini adalah untuk penginputan data mata pelajaran dimana terdapat id mata pelajaran, nama mata pelajaran, hari, durasi belajar, no induk guru dan nama guru.

6) Tampilan Form Data Absensi

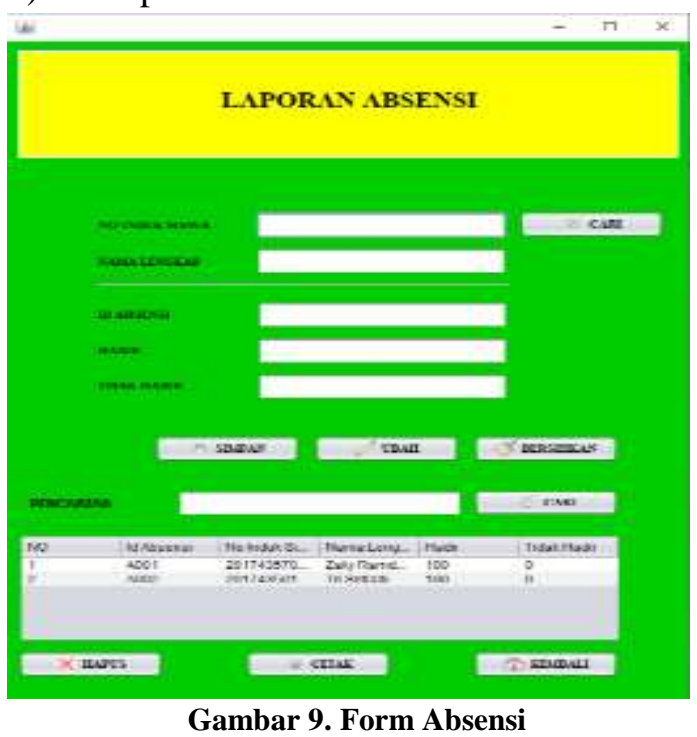

Pada form ini adalah untuk penginputan data absensi dimana terdapat no induk siswa, nama, id absensi, kehadiran, dan ketidak hadiran.
7) Tampilan Form Data Nilai

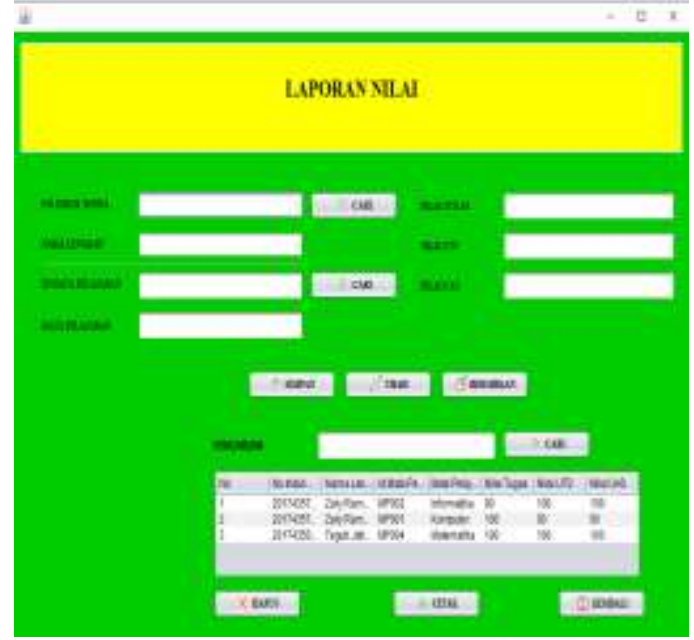

Gambar 10. Form Nilai

Pada form ini adalah untuk penginputan data nilai dimana terdapat no induk siswa, nama, id mata pelajaran, nama mata mata pelajaran, nilai tugas, nilai uts, dan nilai uas.

\section{8) Laporan Data Siswa}

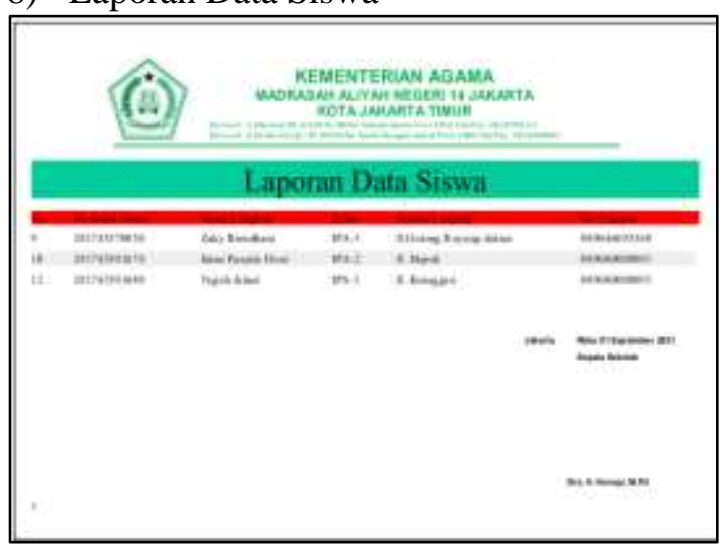

Gambar 11. Laporan Data Siswa

Ini adalah laporan data siswa setelah dicetak, laporan ini bisa di print langsung.

\section{9) Laporan Data Guru}

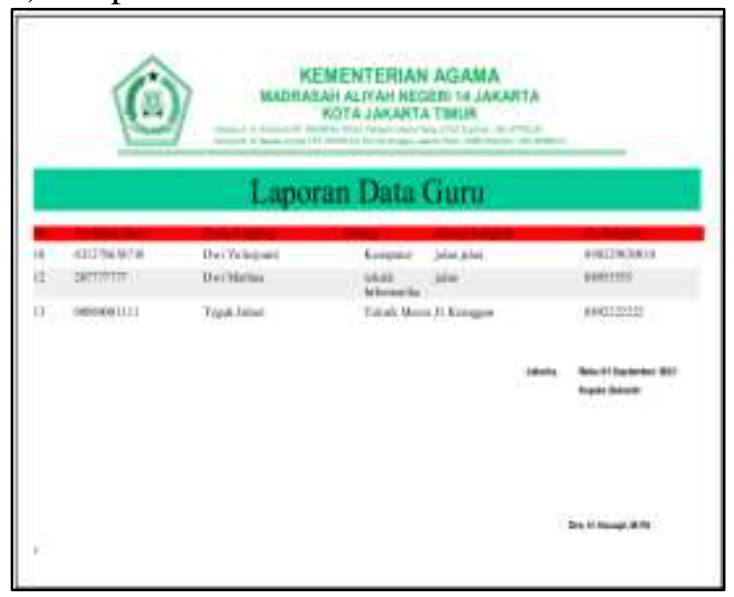

Gambar 12. Laporan Data Guru 
Ini adalah laporan data guru setelah dicetak, laporan ini bisa di print langsung.

10) Laporan Data Mata Pelajaran

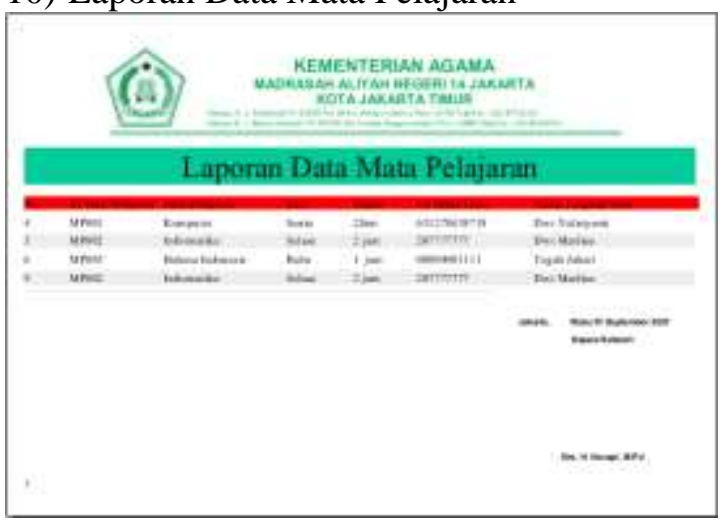

Gambar 13. Laporan Data Mata Pelajaran

Ini adalah laporan data mata pelajaran setelah dicetak, laporan ini bisa di print langsung.

\section{1) Laporan Data Absensi}

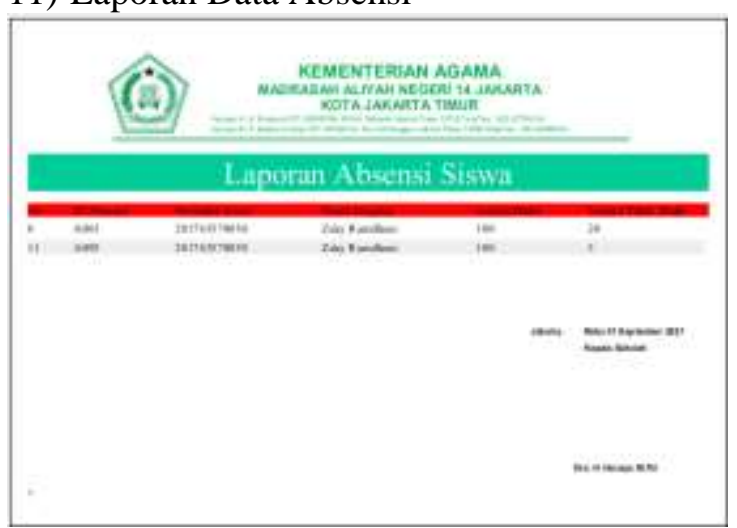

Gambar 14. Laporan Absensi

Ini adalah laporan absensi setelah dicetak, laporan ini bisa di print langsung.

\section{2) Laporan Data Nilai}

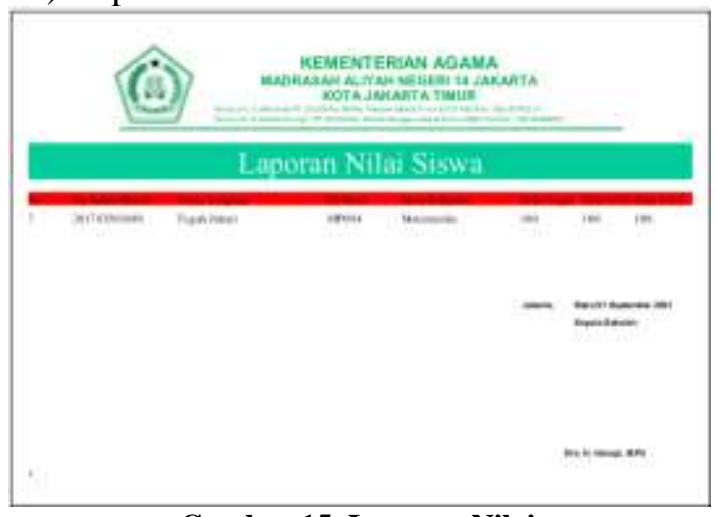

Gambar 15. Laporan Nilai

Ini adalah laporan nilai setelah dicetak, laporan ini bisa di print langsung.

\section{SIMPULAN AN SARAN}

Berdasarkan hasil penelitian dan pembahasan yang telah dilakukan dapat disimpulkan bahwa :

1. Merancang suatu sistem pendataan, terutama pada Madrasah Aliyah Negeri 14 Jakarta Timur yang peneliti tinjau agar dapat memudahkan proses laporan sehingga dapat memberikan hasil yang maksimal terhadap petugas tata usaha.

2. Menyusun sebuah sistem pendataan yang berbasis Java secara sistematis, terstruktur, dan terarah sehingga dapat digunakan oleh Madrasah Aliyah Negeri 14 Jakarta Timur untuk mengatasi sistem yang digunakan masih bersifat manual seperti pencatatan masih menggunakan kertas atau diketik secara manual menggunakan Microsoft Excel.

3. Proses sistem informasi menjadi lebih akurat dan efisien serta penyajian laporan yang lebih terkoordinasi sesuai kebutuhan yang diinginkan.

Berdasarkan hasil tinjauan secara langsung ke Madrasah Aliyah Negeri 14 Jakarta, saya selaku peneliti memiliki saran agar aplikasi ini benar-benar menjadi aplikasi yang dapat mempermudah user dalam melakukan segala aktivitas :

1. Dalam pengembangan selanjutnya diharapkan sistem ini tidak hanya melakukan penyajian sistem informasi maintenance tetapi juga mampu melakukan pencatatan proses administrasi keuangan atau pendaftaran peserta didik baru

2. Pada tahapan selanjutnya, dapat ditambahkan beberapa prosedur enkripsi data yang berguna untuk meningkatkan sistem keamanan data pada aplikasi.

\section{DAFTAR PUSTAKA}

Arizal, D., Cholis, M. N., \& Nusantara, L. S. (2016). Perancangan Aplikasi Penilaian Kinerja Guru di UPT SDN Kebonagung. Universitas Merdeka Pasuruan Jl., 2(1), 15-32.

Djahir dan Pratita. 2015. Sistem Informasi Manajemen. Yogyakarta: CV. Budi Utama.

Hartono, B. (2013). Sistem Informasi Manajemen Berbasis Komputer. In B. Hartono, Sistem Informasi Manajemen Berbasis Komputer. Jakarta: PT Rineka 
Cipta

Widiawati, dan Siradjuddin, HK (2020). Perancangan Website Sistem Seleksi Siswa Baru menggunakan Framework CodeIgniter Pada Madrasah Aliyah Alkhairaat Kalumpang Kota Ternate. Jurnal Ilmiah ILKOMINFO - Ilmu Komputer \& Informatika, 3(2), 6. https://doi.org/10.47324/ilkominfo.v3i2 .105

Rizky, Soetam. (2011). Konsep Dasar Rekayasa Perangkat Lunak (Software Reengineering). Jakarta: PT.Prestasi Pustakaraya

Rizky, S. (2019). Perancangan Sistem Informasi Terpadu Pemerintah Daerah Kabupaten Paser, 53(9), 1689-1699.

Ramzi. (2013). Sanjaya 2015. Paper Knowledge . Toward a Media History of Documents, 5-19.

Sihombing, D (2015). Tipografi dalam Desain Grafis. Jakarta: Gramedia.Sugiyono. (2016a). Metode Deskriptif Kualitatif. Paper Knowledge . Toward a Media History of Documents, 145.

Tata Sutabri, M. (2012a). Pengaruh Pemanfaatan Teknologi Informasi Terhadap Ketepatan Waktu Pelaporan Keuangan Dalam Rangka Mewujudkan Transparansi Dan Akuntabilitas (Studi Pada Kabupaten Minahasa Tenggara). Jurnal EMBA: Jurnal Riset Ekonomi, Manajemen, Bisnis Dan Akuntansi, 4(1), 1. 